\title{
Nitrogen distribution, remobilization and re-cycling in young orchard of non-bearing 'Rocha' pear trees
}

\author{
Cláudia Neto $^{\mathrm{a}, \mathrm{c}, *}$, Corina Carranca ${ }^{\mathrm{a}}$, Josué Clemente ${ }^{\mathrm{b}}$, Amarílis de Varennes ${ }^{\mathrm{c}}$ \\ a L-INIA, Quinta do Marquês, Avenida da República, 2784-505 Oeiras, Portugal \\ ${ }^{\mathrm{b}}$ Selectis, Herdade das Praias, Apartado 120, E.C. Bonfim, 2901-877 Setúbal, Portugal \\ ' Instituto Superior de Agronomia, Technical University of Lisbon, Tapada da Ajuda, 1349-017 Lisboa, Portugal
}

\section{A R T I C L E I N F O}

\section{Article history:}

Received 11 February 2008

Received in revised form 26 March 2008

Accepted 12 June 2008

\section{Keywords:}

Fertigation

Fertilizer ${ }^{15} \mathrm{~N}$ uptake

Fertilizer $\mathrm{N}$ use efficiency

${ }^{15} \mathrm{~N}$ balance

${ }^{15} \mathrm{~N}$ re-cycling

Pyrus communis $\mathrm{L}$

\begin{abstract}
A B S T R A C T
In newly planted orchards, special attention must be paid to fertilization to build up the permanent structure of the trees so that high yield and fruit quality can be reached later on. Nitrogen $(\mathrm{N})$ plays a major role in the fertilization plan, although few studies have assessed its use efficiency in young nonbearing trees, especially in field conditions. In this work, 1-3 years old 'Rocha' pear trees, grafted on quince BA29, were planted in a Mediterranean region, and fertigated with $6 \mathrm{~g} \mathrm{~N}$ tree $^{-1} \mathrm{year}^{-1}$ as ammonium nitrate with 5 at.\% ${ }^{15} \mathrm{~N}$ enrichment to study the fertilizer $\mathrm{N}$ uptake during the vegetative cycle, the overall fertilizer $\mathrm{N}$ use efficiency at the end of each year, and the plant-soil $\mathrm{N}$ balance for this period. Nitrogen remobilization and the re-cycling of $\mathrm{N}$ from senescent leaves were also studied by fertilizing some pear trees with 10 at. $\%{ }^{15} \mathrm{~N}$ enrichment.

Nitrogen uptake was minimum at bud break and peaked in June/July remaining more or less constant until leaf fall. About $25 \%$ of the fertilizer $\mathrm{N}$ taken up by 3 years old trees in the previous year was found in the new tissues formed (flowers, leaves and 1-year-old shoots), reaching $27 \%$ when fine roots were also included. In those trees, $32 \%$ and $54 \%$ of the ${ }^{15} \mathrm{~N}$ stored in the previous year in the trunk and older shoots, respectively, were mobilized to the new growth in the following year.

Fertilizer $\mathrm{N}$ use efficiency by trees increased from the first to the third year but was generally small (6\%, $14 \%$ and $33 \%)$, and estimated $N$ losses were large (89\%, $46 \%$ and $53 \%$, respectively in the first, second and third years). Irrigation water and soil provided more $\mathrm{N}$ to the trees than fertilizer $\mathrm{N}$.
\end{abstract}

(c) 2008 Elsevier B.V. All rights reserved.

\section{Introduction}

Nitrogen $(\mathrm{N})$ is commonly associated with tree growth and vigour, two characteristics that, if managed with care, are of the outmost importance for the development of newly planted trees so that they are able to maximize their flower production and yield potential. Too much vigour can be a result of $\mathrm{N}$ imbalance and can compromise the onset of bearing or even the yield in the first years. Some fertilization plans recommend $\mathrm{N}$ application since the beginning of bud break until 6 weeks after full bloom for bearing pear trees (Gonçalves et al., 1997; Luz et al., 2005; Cavaco et al., 2006), whereas others defend that $\mathrm{N}$ must be applied during the whole growth cycle (Quartieri et al., 1996; Raese, 1997)

\footnotetext{
* Corresponding author at: Instituto Superior de Agronomia, Technical University of Lisbon, Tapada da Ajuda, 1349-017 Lisboa, Portugal. Tel.: +351 916847479; fax: +351302011165.

E-mail address: claudia.bneto@sapo.pt (C. Neto).
}

considering that after harvest trees can still improve their reserves through $\mathrm{N}$ uptake from the soil. Furthermore, $\mathrm{N}$ fertilization must be guided by environmental concerns which comprise its susceptibility to leaching (especially in the nitrate form), and also $\mathrm{N}$ re-cycling as a consequence of leaf fall, pruning wood and root death. Although some authors have studied the fertilizer $\mathrm{N}$ use efficiency in pears and apples (Millard and Neilsen, 1989; Cheng et al., 2001, 2004; Neilsen et al., 2001a), most studies were performed in pots and in sand culture, compromising its applicability to field conditions. The re-cycling of $\mathrm{N}$, as a result of the decomposition of senescent leaves in soils, was only addressed in one study with apple trees (Tagliavini et al., 2004, 2007).

The objectives of the present work were to study: (i) the fertilizer N uptake during the growth cycle of $1-3$ years old 'Rocha' pear trees grown in the field; (ii) the $\mathrm{N}$ remobilization within the tree; (iii) the overall fertilizer $\mathrm{N}$ use efficiency at the end of each year; (iv) $\mathrm{N}$ re-cycling from the decomposition of senescent leaves in the orchard. 


\section{Materials and methods}

\subsection{Site and experimental layout}

In March 2003, 'Rocha' pear trees (Pyrus communis L.) grafted on quince (Cydonia oblonga Mill.) BA29 were planted in a $1.5 \mathrm{~m} \times 4.0 \mathrm{~m}$ spacing, in Pêro Moniz, Cadaval (39 $14^{\prime} \mathrm{N} ; 9^{\circ} 06^{\prime} \mathrm{W} ; 70 \mathrm{~m}$ altitude), located at 'Ribatejo e Oeste' region (west Portugal). The bare-rooted trees were planted after medium root pruning (30\% volume reduction).

The soil (Anthrosol, FAO-ISRIC-ISSS, 1998) had a sandy-loam texture with a bulk density of $1.3 \mathrm{~g} \mathrm{~cm}^{-3}$, slightly acidic $\mathrm{pH}_{\left(\mathrm{H}_{2} \mathrm{O}\right)}$ (5.4) and low organic matter and $\mathrm{N}$ content $\left(12.0 \mathrm{~g} \mathrm{~kg}^{-1}\right.$ and $0.5 \mathrm{~g} \mathrm{~kg}^{-1}$, respectively). Lime was applied to the soil in the two first years of the experiment, at a rate of $1.2 \mathrm{tha}^{-1}$ year $^{-1}$ as calcium carbonate in order to increase $\mathrm{pH}$ to about 6.5 (Ojea and Taboadela, 1957), the optimum $\mathrm{pH}$ value for pear nutrition and nutrient availability in the soil. Soil pH rose to 6.6 at the end of the third year, and leaf micronutrient concentrations in pear trees were always above or at optimum level (data not shown).

The climate of the region is characterized by mild autumns and winters and hot and dry summers, a Mediterranean-type climate. Mean air temperatures ranged from $7.2{ }^{\circ} \mathrm{C}$ to $10.9{ }^{\circ} \mathrm{C}$ in January/ February to $21.6{ }^{\circ} \mathrm{C}$ to $23.0^{\circ} \mathrm{C}$ in July/August. Minimum air temperatures varied from $-0.4{ }^{\circ} \mathrm{C}$ to $17.5^{\circ} \mathrm{C}$ from March 2003 to December 2005, and maximum air temperatures, in the same period, ranged from $15.2{ }^{\circ} \mathrm{C}$ to $31.4{ }^{\circ} \mathrm{C}$. Total rainfall in 2003 (March-December), and in 2004 and 2005 (January-December) was $850 \mathrm{~mm}, 620 \mathrm{~mm}$, and $556 \mathrm{~mm}$, respectively. Only in June of 2004 and 2005 the precipitation was almost absent (less than $5 \mathrm{~mm}$ ), although in July and August there was less rainfall than during the rest of the year (on average $15 \mathrm{~mm}$ per month). Rainfall was greater from October to December 2003 (on average $186 \mathrm{~mm}$ per month), October $2004(180 \mathrm{~mm})$ and October to November 2005 (on average $138 \mathrm{~mm}$ per month).

Over the 3 years (2003-2005), 35 trees were drip fertigated ( $1 \mathrm{~h}$ per day) from April to October with $3.61 \mathrm{~h}^{-1}$ emitters, spaced at $0.75 \mathrm{~m}$ in the planting row. The volume of irrigation water applied was 8641 tree $^{-1}$ in 2003 and 2005, and 9361 tree $^{-1}$ in 2004. Phosphorus (15 kg P ha ${ }^{-1}$ year $\left.^{-1}\right)$ and potassium $(50 \mathrm{~kg}$ $\mathrm{K} \mathrm{ha}^{-1}$ year $^{-1}$ ) were applied as potassium dihydrogen phosphate and potassium sulphate, according to national Integrated Fruit Production (IFP) guidelines for pear trees (Gonçalves et al., 1997).

\subsection{Nitrogen uptake during the growth cycle}

Fifteen pear trees (planted in March 2003) were fertilized with $10 \mathrm{~kg} \mathrm{~N} \mathrm{ha}^{-1}$ year $^{-1}\left(6 \mathrm{~g} \mathrm{~N}\right.$ tree $^{-1}$ year $\left.^{-1}\right)$ as ammonium nitrate during the first 3 years after planting. Each year, in a set of five trees (completely randomized design with five replications) the fertilizer was distributed manually and was doubly enriched with 5 at.\% ${ }^{15} \mathrm{~N}$, being applied in the wetting zone of the emitters and split as follows: $60 \%$ from April to June (20\% in each month), and $40 \%$ from July to October ( $10 \%$ in each month), according to national IFP guidelines (Gonçalves et al., 1997) and standard practice by pear growers.

In the five trees labelled with ${ }^{15} \mathrm{~N}$ leaf sampling (mid third of newly formed shoots) was monthly performed from May until leaf fall (November of 2003, and December of 2004 and 2005). Leaves were analyzed for total $\mathrm{N}$ and $\%{ }^{15} \mathrm{~N}$ enrichment (mass spectrometry). Nitrogen withdrawal from senescent leaves to perennial storage organs before leaf fall was calculated as the difference between the amount of $\mathrm{N}$ in leaves in August (growth cessation) and the amount of $\mathrm{N}$ at leaf fall (Neilsen et al., 2001a), assuming a constant leaf weight during this period.

\subsection{Tree growth and $N$ partitioning}

At planting (March 2003) five pear trees coming from the nursery were root pruned and then washed, dried $\left(65^{\circ} \mathrm{C}\right.$ during at least $48 \mathrm{~h}$ ), weighed to calculate the dry weight (DW), ground $(<0.5 \mathrm{~mm})$ and analyzed for total $\mathrm{N}$ (Kjeldahl). A group of 15 pear trees were planted and fertilized with $10 \mathrm{~kg} \mathrm{~N}^{-1}$ year $^{-1}$ ( $6 \mathrm{~g} \mathrm{~N}$ tree ${ }^{-1} \mathrm{year}^{-1}$ ) as ammonium nitrate during the following 3 years, and in each year a set of 5 trees was labelled with ${ }^{15} \mathrm{~N}$, similarly to the trees described in 2.2. After leaf fall, in November 2003, January 2005 and January 2006, the five trees labelled with ${ }^{15} \mathrm{~N}$ were removed from the soil (destructive harvest, excavated manually).

Growth was evaluated in each harvested tree by measuring the trunk perimeter and tree height $(20 \mathrm{~cm}$ above the grafting area (Jordão, 2002)), the 1-year-old shoot length, the maximum root depth, and the root length in the row and between rows. The trunk cross-sectional area (TCSA) was calculated, based on the trunk perimeter, according to Westwood (1993), and maximum root volume was calculated as the product of maximum root depth, root length in the row, and root length between rows, assuming a parallelepiped geometry. The harvested trees were then separated into fine roots ( $<2 \mathrm{~mm}$ diameter), coarse roots ( $\geq 2 \mathrm{~mm}$ diameter), trunk, shoots ( 1 year, 2 years $(n-1)$ and 3 years old $(n-2)$ ), leaves (senescent leaves) and flowers (only in the third year, consisting in all open flowers collected during the blooming period). The tree fractions were washed, dried $\left(65^{\circ} \mathrm{C}\right.$ during at least $\left.48 \mathrm{~h}\right)$, weighed to calculate the DW, ground $(<0.5 \mathrm{~mm})$ and analyzed for total $\mathrm{N}$ and $\%{ }^{15} \mathrm{~N}$ enrichment.

\subsection{Remobilization of internal $N$ and source of $N$}

Five pear trees fertilized with $10 \mathrm{~kg} \mathrm{~N}$ ha $^{-1}$ year $^{-1}\left(6 \mathrm{~g} \mathrm{~N}\right.$ tree ${ }^{-1}$ year $^{-1}$ ) as ammonium nitrate during the first year after planting (March 2003) were labelled in 2004 with ${ }^{15} \mathrm{~N}$ as ammonium nitrate doubly enriched with 10 at. $\%{ }^{15} \mathrm{~N}$, and fertilized with unlabelled $\mathrm{N}$ in 2005 (same $\mathrm{N}$ fertilizer type and rate). These five trees were destructively harvested at the end of leaf fall (January 2006) and processed as described for the labelled trees in Section 2.3 .

\subsection{Nitrogen re-cycling from mineralization of fallen leaves}

Five 4 years old pear trees randomly chosen and only fertilized with P and $K$ since planting (March 2003) (showing, nevertheless, similar TCSA and tree heigh as N fertilized trees), were fertilized with $10 \mathrm{~g}$ DW of intact senescent pear leaves containing $15.1 \mathrm{~g} \mathrm{~N} \mathrm{~kg}^{-1} \mathrm{DW}$ (151 mg N tree ${ }^{-1}$ ) and enriched with 1.38 at.\% ${ }^{15} \mathrm{~N}$, placed in the two sides of the row of each tree $(5 \mathrm{~g}$ DW in each side of the tree). These leaves were placed directly on the soil surface at bud break (March 2006), in an area of $0.04 \mathrm{~m}^{2}$ in each side of the tree, and covered by a nylon net (to prevent disturbance by wind or fauna). In August of the same year, a sample of 20 leaves from the mid third of newly formed shoots was collected per tree and analyzed for total $\mathrm{N}$ and $\%{ }^{15} \mathrm{~N}$ enrichment, to evaluate if any ${ }^{15} \mathrm{~N}$ coming from the decomposition of those senescent leaves was absorbed by the pear trees.

\subsection{Soil and water sampling}

Soil sampling was annually performed, at the end of the growth cycle ( 1 month after the last fertilization). Samples were collected in the moistened bulb zones and were air-dried, sieved $(<0.5 \mathrm{~mm})$ and analyzed for $\mathrm{pH}_{\left(\mathrm{H}_{2} \mathrm{O}\right)}$, organic carbon (C) and total $\mathrm{N}$, mineral $\mathrm{N}$ $\left(\mathrm{NH}_{4}{ }^{+}+\mathrm{NO}_{3}{ }^{-}\right)$and $\%{ }^{15} \mathrm{~N}$ enrichment. 
Irrigation water was monthly sampled and analyzed for mineral $\mathrm{N}\left(\mathrm{NO}_{3}{ }^{-}+\mathrm{NH}_{4}{ }^{+}\right)$, to estimate total $\mathrm{N}$ provided each year by this source.

\subsection{Calculations and statistical approach}

Nitrogen derived from the fertilizer in each plant organ $\left(\% \mathrm{Ndff}_{\mathrm{p}}\right)$ or in the soil $\left(\% \mathrm{Ndff}_{\mathrm{s}}\right)$, the ${ }^{15} \mathrm{~N}$ recovered in each plant organ $(\mathrm{mg})$ or in the soil (residual ${ }^{15} \mathrm{~N}, \mathrm{mg}$ ) and the fertilizer $\mathrm{N}$ use efficiency (\%FNUE) by the trees were determined according to Carranca et al. (1999):

$\% \mathrm{Ndff}=\left(\frac{\text { at. } \%{ }^{15} \mathrm{~N} \text { excess of sample }(\text { organ } / \text { soil })}{\text { at. } \%{ }^{15} \mathrm{~N} \text { excess of fertilizer }}\right) \times 100$

Recovered ${ }^{15} \mathrm{~N}(\mathrm{mg})=$ total $\mathrm{N}\left(\mathrm{g} \mathrm{kg}^{-1}\right)$ in the sample (organ/soil)

$$
\times \% \text { Ndff }(\text { organ } / \text { soil })
$$

$\% \mathrm{FNUE}=\left(\frac{\text { recovered }{ }^{15} \mathrm{~N} \text { in the tree }(\mathrm{mg})}{\mathrm{N} \text { applied }(\mathrm{mg})}\right) \times 100$

The $\mathrm{N}$ balance in the soil-plant system, as a result of the $\mathrm{N}$ fertilization in each of the 3 years was determined as follows:

N balance $=$ N applied $\left(\right.$ g tree $^{-1}$ year $\left.^{-1}\right)$

$$
\begin{aligned}
& -\left[{ }^{15} \mathrm{~N} \text { recovered in the tree }\left(\mathrm{g} \mathrm{tree}^{-1} \mathrm{year}^{-1}\right)\right. \\
& \left.+\operatorname{residual}^{15} \mathrm{Nin} \text { the soil }\left(\mathrm{g} \mathrm{tree}^{-1} \text { year }^{-1}\right)\right]
\end{aligned}
$$

Unrecovered ( $\mathrm{N}$ remaining after the subtraction) represented the $\mathrm{N}$ losses which can be a result of leaching, gaseous losses, or losses from the unrecovered fine and dead roots, fallen leaves, or flowers.

Data were analyzed for variance by the General Linear Model using the SPSS 11.0 package. Means separation were performed using the post hoc Schéffé's test $(p<0.05)$. In the text, means and standard deviations were sometimes included. Linear regression equations were fitted $(p<0.001)$ for tree components, over the 3 year experiment.

\section{Results}

\subsection{Nitrogen uptake during the growth cycle}

The variation of $\mathrm{N}$ concentration in leaves from the mid third of newly formed shoots was similar in the 3 years from May to July, with a sharp decrease from May to June (Fig. 1A). In the first year, $N$ concentration was similar from July to leaf fall, whereas in the second and third years leaf $\mathrm{N}$ was smaller at the end of the vegetative cycle (senescent leaves). When comparing the amount of $\mathrm{N}$ in senescent leaves with leaf $\mathrm{N}$ content in August we observed that $\mathrm{N}$ withdrawal from senescent leaves to perennial storage organs before leaf fall was absent in the first year, was very low in the second year (10\%), increasing with tree age (28\% in the third year).

In years 1 and 2 , the \% $\mathrm{N}$ derived from the fertilizer (\%Ndff) in the leaves from the mid third of newly formed shoots (Fig. 1B) increased from $<5 \%$ Ndff in May to $12 \%$ Ndff in August remaining stable thereafter. This increase was slower in the first year than in the second. In the third year, no significant differences in the \%Ndff were observed during the growth cycle, although a trend for slightly lower values in May and December was observed.

\subsection{Tree growth and $N$ partitioning}

Tree height increased from $165 \mathrm{~cm}$ to $244 \mathrm{~cm}$, from years 1 to 3 , and the trunk cross-sectional area varied from $2.2 \mathrm{~cm}^{2}$ to $15.7 \mathrm{~cm}^{2}$
(Table 1 ). Shoot length did not vary significantly from year to year (on average $23 \mathrm{~cm}$ ). The maximum root depth increased from about $30 \mathrm{~cm}$ at the end of the first year to more than $60 \mathrm{~cm}$ in the third year, and maximum root length in the row and between rows varied, respectively, from around $30 \mathrm{~cm}$ to $90 \mathrm{~cm}$, and from $30 \mathrm{~cm}$ to $60 \mathrm{~cm}$ (Table 1 ). The maximum root volume of 3 years old pear trees was about 10 times greater than volume in the first year.

Total biomass accumulated by the plants at the end of each vegetative cycle (Table 2 ) increased from $182 \mathrm{~g}$ (in the nursery) to $2446 \mathrm{~g}$ (in the third year). The tree trunk and the coarse roots had the greatest dry weights in each year. The DW of coarse roots and new shoots represented constant proportions relatively to total tree biomass ( 0.34 and 0.10 , respectively). In contrast, the DW of trunk, senescent leaves and fine roots represented a smaller proportion in relation to the total tree biomass as trees aged. The aboveground/belowground ratio increased with tree age from 0.9 (in the nursery) to 1.7 (in the third year).

The \%Ndff in the trees was similar for all plant organs in the first and second years after planting (corresponding to an average of $10 \%$ ) (Table 2), but in the third year the \%Ndff was greater in the fine roots (around 13\%) and smaller in the senescent leaves (7\%).

Nitrogen content in the trees coming from the nursery was $1.35 \mathrm{~g}$ per tree and 1 year later it was $3.87 \mathrm{~g}$ (Table 2 ). In the second year, $\mathrm{N}$ accumulated by the tree rose to $8.12 \mathrm{~g}$, and finally, it was $21.60 \mathrm{~g} N$ per tree in the third year. Total $\mathrm{N}$ content of tree parts or of each plant organ during the first 3 years after planting was linearly related to TCSA (Table 3) clearly showing the strong dependence between trunk perimeter and tree $\mathrm{N}$ nutrition, as expected.

The $\mathrm{N}$ content and the ${ }^{15} \mathrm{~N}$ recovered in the tree were always greatest in the trunk and coarse roots and smallest in the fine roots (Table 2) because of their small biomass. The estimated \%FNUE for the non-bearing pear trees varied from $6 \%$ to $14 \%$ and $33 \%$ in the
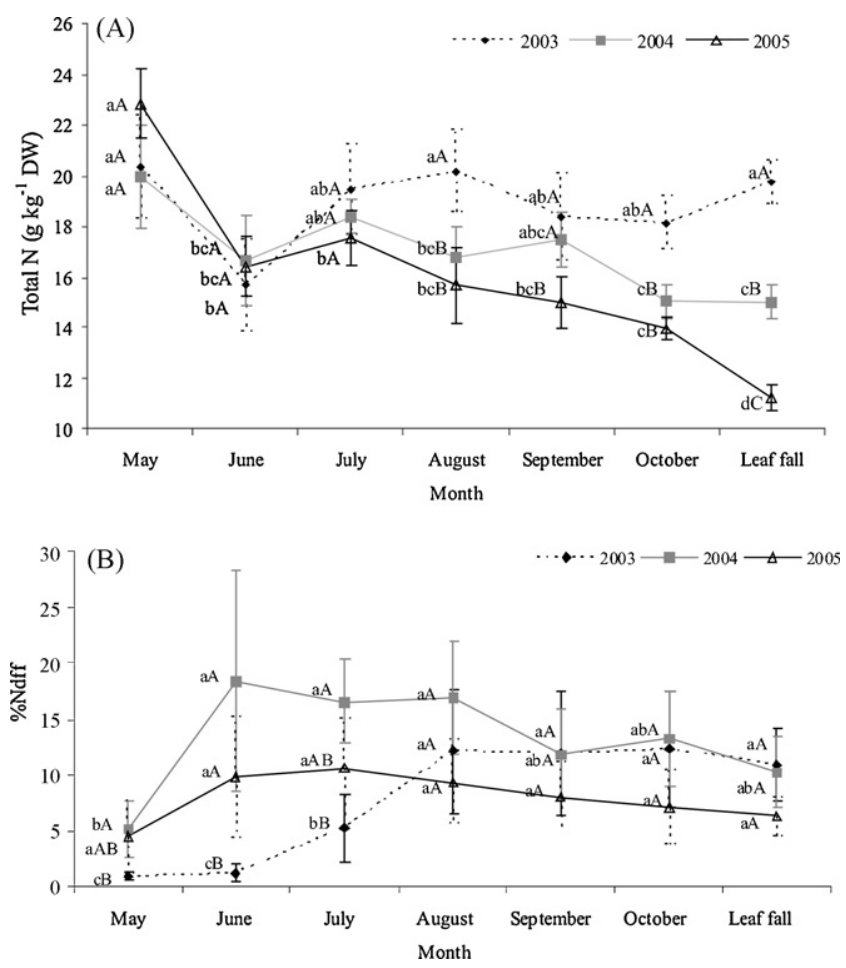

Fig. 1. Total leaf $\mathrm{N}\left(\mathrm{g} \mathrm{kg}^{-1} \mathrm{DW}\right)$ (A) and \% $\mathrm{N}$ derived from the fertilizer (\%Ndff) (B) in 1 to 3 years old 'Rocha' pear trees, during the growth cycle (2003-2005). Means with different small letters differ significantly (Shéffé's test, $p<0.001$ ) between dates, for each year; means with different capital letters differ significantly (Shéffé's test, $p<0.001$ ) between years, for each date. 
Table 1

Growth of non-bearing 'Rocha' pear trees fertilized with $6 \mathrm{~g} \mathrm{~N}$ tree $^{-1}$ year $^{-1}$ as ammonium nitrate

\begin{tabular}{|c|c|c|c|c|c|c|}
\hline Year & $\begin{array}{l}\text { TCSA } \\
\left(\mathrm{cm}^{2}\right)\end{array}$ & $\begin{array}{l}\text { Tree height } \\
(\mathrm{cm})\end{array}$ & $\begin{array}{l}\text { Max. root } \\
\text { depth }(\mathrm{cm})\end{array}$ & $\begin{array}{l}\text { Max. root length } \\
\text { in row }(\mathrm{cm})\end{array}$ & $\begin{array}{l}\text { Max. root length } \\
\text { between rows }(\mathrm{cm})\end{array}$ & $\begin{array}{l}\text { Max. root volume } \\
\left(\mathrm{m}^{3} \text { tree }^{-1}\right)\end{array}$ \\
\hline 1 (2003) & $2.2 \mathrm{c}$ & $165 \mathrm{~b}$ & $32 \mathrm{~b}$ & $31 \mathrm{c}$ & $30 \mathrm{~b}$ & $0.03 \mathrm{~b}$ \\
\hline $2(2004)$ & $7.0 \mathrm{~b}$ & $208 \mathrm{ab}$ & 58 a & $73 \mathrm{~b}$ & $56 a$ & $0.24 \mathrm{a}$ \\
\hline $3(2005)$ & $15.7 \mathrm{a}$ & $244 \mathrm{a}$ & $62 \mathrm{a}$ & $86 \mathrm{a}$ & $60 \mathrm{a}$ & $0.32 \mathrm{a}$ \\
\hline
\end{tabular}

TCSA, trunk cross-sectional area; Max., maximum. Different letters in the same column differ significantly (Schéffé's test, $p<0.05$ ).

first, second and third years after planting, respectively, increasing significantly $(p<0.05)$ from year to year.

\subsection{Remobilization of internal $N$ and source of $N$}

The 3 years old trees labelled in the year before with ${ }^{15} \mathrm{~N}$ presented similar plant biomass $\left(2070 \pm 450 \mathrm{~g} \mathrm{DW}\right.$ tree $^{-1}$ ) (Table 4$)$ as those labelled in the current season $\left(2446 \pm 703 \mathrm{~g}^{-1} \mathrm{tree}^{-1}\right)$ (Table 2), which lead us to assume a similar behaviour for these two groups.

The total ${ }^{15} \mathrm{~N}$ recovered in the 2 years old trees (labelled in the current season) was $778 \pm 68 \mathrm{mg}{ }^{15} \mathrm{~N}$ (total ${ }^{15} \mathrm{~N}$ recovered by the trees minus the ${ }^{15} \mathrm{~N}$ exported by the respective senescent leaves) and did not differ from the ${ }^{15} \mathrm{~N}$ recovered in the 3 years old trees labelled in the year before $\left(763 \pm 25 \mathrm{mg}{ }^{15} \mathrm{~N}\right)$, supporting the comparisons between these two groups of trees, in terms of remobilized N.

Most of the ${ }^{15} \mathrm{~N}$ from the fertilizer absorbed in the previous year was accumulated in the trunk and coarse roots (Table 4). This ${ }^{15} \mathrm{~N}$ represented $28 \%$ and $32 \%$, respectively, of the total amount of ${ }^{15} \mathrm{~N}$ in the tree, whereas the new organs developed in 2005 (flowers, leaves and 1-year-old shoots) accumulated $25 \%$ of the total ${ }^{15} \mathrm{~N}$ in the tree. This value represented the remobilization of $\mathrm{N}$ from the fertilizer absorbed and stored in the previous year. If the fine roots were also included, then the value reached $27 \%$ of the total ${ }^{15} \mathrm{~N}$ in the tree.

The difference between the ${ }^{15} \mathrm{~N}$ content in the trunk of 2 years old trees (Table 2) (312 $\mathrm{mg}$ tree $^{-1}$ ) and the correspondent amount in the 3 years old trees (labelled in the previous season) (212 $\mathrm{mg}$ tree ${ }^{-1}$ ) (Table 4) resulted in a loss of $100 \mathrm{mg}$ of ${ }^{15} \mathrm{~N}$ per tree, representing a remobilization of $32 \%$ of the ${ }^{15} \mathrm{~N}$ stored in this organ.

The ${ }^{15} \mathrm{~N}$ content of all shoots $[(n)+(n-1)](228 \mathrm{mg}$ per tree) in the 2 years old trees (Table 2 ) was $122 \mathrm{mg}$ greater than the amount of ${ }^{15} \mathrm{~N}$ recovered in the equivalent shoots $[(n-1)+(n-2)]$ of 3 years old trees (Table 4), representing a remobilization of $54 \%$ of the stored ${ }^{15} \mathrm{~N}$ in these organs. In contrast, the amount of ${ }^{15} \mathrm{~N}$ from the fertilizer present in the fine and coarse roots of 2 years old

Table 2

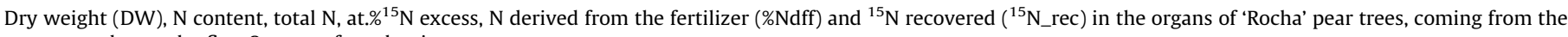
nursery and over the first 3 years after planting

\begin{tabular}{|c|c|c|c|c|c|}
\hline Organ & DW $\left(\mathrm{g} \mathrm{tree}^{-1}\right)$ & Total $\mathrm{N}\left(\mathrm{g} \mathrm{kg}^{-1}\right)$ & $\mathrm{N}$ content $\left(\mathrm{g}\right.$ tree $\left.^{-1}\right)$ & $\operatorname{Ndff}(\%)$ & ${ }^{15} \mathrm{~N} \_$rec $\left(\mathrm{mg}\right.$ tree $\left.{ }^{-1}\right)$ \\
\hline \multicolumn{6}{|l|}{ Nursery } \\
\hline Trunk & $83 \mathrm{aD}$ & $7.8 \mathrm{aB}$ & $0.65 \mathrm{aC}$ & - & - \\
\hline Fine roots & $8 \mathrm{bC}$ & $8.9 \mathrm{aAB}$ & $0.07 \mathrm{bC}$ & - & - \\
\hline Coarse roots & $91 \mathrm{aC}$ & $7.0 \mathrm{aAB}$ & $0.63 \mathrm{aC}$ & - & - \\
\hline Total & $182 \mathrm{D}$ & & $1.35 \mathrm{D}$ & & \\
\hline \multicolumn{6}{|c|}{ First year after planting } \\
\hline Sen. leaves & $29 \mathrm{bB}$ & $20.0 \mathrm{aA}$ & $0.58 \mathrm{bcB}$ & $6.2 \mathrm{a}$ & $37 \mathrm{bB}$ \\
\hline Trunk & $115 \mathrm{aC}$ & $15.0 \mathrm{bA}$ & $1.70 \mathrm{aB}$ & $10.5 \mathrm{a}$ & $178 \mathrm{aB}$ \\
\hline Fine roots & $23 \mathrm{bB}$ & $10.9 \mathrm{cdA}$ & $0.25 \mathrm{cB}$ & $12.7 \mathrm{a}$ & 32 bB \\
\hline Coarse roots & $101 \mathrm{aC}$ & $9.6 \mathrm{dA}$ & $0.98 \mathrm{bB}$ & $9.2 \mathrm{a}$ & $95 \mathrm{abB}$ \\
\hline Shoots & $27 \mathrm{bB}$ & $13.4 \mathrm{bcA}$ & $0.36 \mathrm{cB}$ & $9.9 \mathrm{a}$ & 35 bB \\
\hline Total & $296 \mathrm{C}$ & & $3.87 \mathrm{C}$ & & $376 \mathrm{C}$ \\
\hline \multicolumn{6}{|c|}{ Second year after planting } \\
\hline Sen. leaves & $60 \mathrm{bB}$ & $15.1 \mathrm{aB}$ & $0.90 \mathrm{cbB}$ & $6.7 \mathrm{a}$ & $58 \mathrm{bcB}$ \\
\hline Trunk & $335 \mathrm{aB}$ & $9.2 \mathrm{cB}$ & $3.04 \mathrm{aB}$ & $10.4 \mathrm{a}$ & $312 \mathrm{aB}$ \\
\hline Fine roots & 39 bAB & $6.9 \mathrm{~dB}$ & $0.27 \mathrm{cB}$ & $9.4 \mathrm{a}$ & $26 \mathrm{cB}$ \\
\hline Coarse roots & $332 \mathrm{aB}$ & $5.5 \mathrm{~dB}$ & $1.84 \mathrm{bB}$ & $11.6 \mathrm{a}$ & $212 \mathrm{abB}$ \\
\hline Shoots & $96 \mathrm{bA}$ & $10.2 \mathrm{cB}$ & $0.96 \mathrm{bcB}$ & $11.6 \mathrm{a}$ & $114 \mathrm{bcB}$ \\
\hline Shoots $(n-1)$ & $96 \mathrm{bA}$ & $11.8 \mathrm{bA}$ & $1.11 \mathrm{bcB}$ & $10.6 \mathrm{a}$ & $114 \mathrm{bcA}$ \\
\hline Total & $958 \mathrm{~B}$ & & 8.12 B & & 836 B \\
\hline \multicolumn{6}{|c|}{ Third year after planting } \\
\hline Sen. leaves & $128 \mathrm{bA}$ & $11.2 \mathrm{bcB}$ & $1.44 \mathrm{cA}$ & $7.3 \mathrm{c}$ & $102 \mathrm{cA}$ \\
\hline Trunk & 752 aA & $8.7 \mathrm{cdB}$ & $6.59 \mathrm{aA}$ & $9.2 \mathrm{abc}$ & $604 \mathrm{aA}$ \\
\hline Fine roots & $55 \mathrm{bA}$ & $7.8 \mathrm{~dB}$ & $0.43 \mathrm{cA}$ & $12.7 \mathrm{a}$ & $54 \mathrm{cA}$ \\
\hline Coarse roots & $838 \mathrm{aA}$ & $6.4 \mathrm{~dB}$ & $5.22 \mathrm{abA}$ & 8.6 bc & $446 \mathrm{abA}$ \\
\hline Shoots & $245 \mathrm{bA}$ & $10.7 \mathrm{bcB}$ & $2.60 \mathrm{bcA}$ & $11.5 \mathrm{ab}$ & 288 bcA \\
\hline Shoots $(n-1)$ & $249 \mathrm{bA}$ & $12.4 \mathrm{bA}$ & $3.04 \mathrm{bcA}$ & $9.6 \mathrm{abc}$ & $280 \mathrm{bcA}$ \\
\hline Shoots $(n-2)$ & $174 \mathrm{~b}$ & $12.6 \mathrm{~b}$ & $2.14 \mathrm{c}$ & $9.1 \mathrm{bc}$ & 192 bc \\
\hline Flowers & $5 c$ & $29.2 \mathrm{a}$ & $0.14 \mathrm{~d}$ & & \\
\hline Total & 2446 A & & $21.60 \mathrm{~A}$ & & 1966 A \\
\hline
\end{tabular}

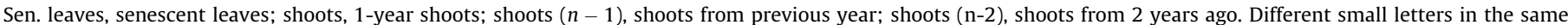

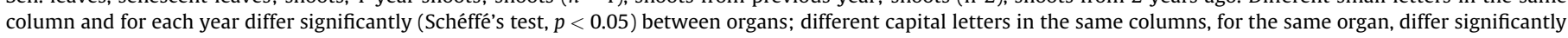
(Schéffé's test, $p<0.05$ ) between years. 
Table 3

Linear regression equations $(y=a x)$ parameters for the relationships between exported N ( $\mathrm{g} \mathrm{N}^{-1} \mathrm{tre}^{-1}$ or organ ${ }^{-1}$ ) and trunk cross-sectional area $\left(\mathrm{cm}^{2}\right)$ of 'Rocha' pear trees, over the first 3 years after planting $(n=15)$

\begin{tabular}{llll}
\hline$y$ & Slope $(a)$ & $R^{2}$ & $p$ \\
\hline Total tree & 1.34 & 0.91 & $<0.001$ \\
Aboveground & 0.99 & 0.89 & $<0.001$ \\
$\quad$ Senescent leaves & 0.10 & 0.92 & $<0.001$ \\
Trunk & 0.43 & 0.96 & $<0.001$ \\
Shoots & 0.16 & 0.86 & $<0.001$ \\
Shoots (n-1) and (n-2) & 0.16 & 0.79 & $<0.001$ \\
Belowground & 0.35 & 0.89 & $<0.001$ \\
Fine roots & 0.03 & 0.82 & $<0.001$ \\
Coarse roots & 0.32 & 0.97 & $<0.001$ \\
\hline
\end{tabular}

$y$, exported $\mathrm{N}\left(\mathrm{g} \mathrm{N}\right.$ tree ${ }^{-1}$ or organ $\left.{ }^{-1}\right) ; x$, trunk cross-sectional area $\left(\mathrm{cm}^{2}\right) ; R^{2}$, coefficient of determination; $p$, probability level.

trees $\left(238 \pm 56 \mathrm{mg}^{-1}\right.$ tree $\left.^{-1}\right)$ (Table 2 ) was similar to the amount of ${ }^{15} \mathrm{~N}$ accumulated 1 year later in the coarse roots $\left(241 \pm 51 \mathrm{mg}\right.$ tree $\left.{ }^{-1}\right)$ (Table 4), suggesting that no net remobilization of ${ }^{15} \mathrm{~N}$ occurred in this organ.

The ${ }^{15} \mathrm{~N}$ mobilized from the storage organs (mainly trunk and older shoots) was recovered in the new shoots $\left(106 \mathrm{mg}^{-1} \mathrm{e}^{-1}\right)$ of the 3 years old trees, as well as in the leaves $\left(72 \mathrm{mg}\right.$ tree $\left.^{-1}\right)$, flowers $\left(11 \mathrm{mg} \mathrm{tree}^{-1}\right.$ ) and fine roots (15 $\mathrm{mg} \mathrm{tree}^{-1}$ ) (Table 4$)$.

Taking into account the values in Tables 2 and 4, the amount, source and age of $N$ present in the different plant organs of 3 years old pear trees at the end of leaf fall could be assessed (Table 5). In this case, the total $\mathrm{N}$ content in the different plant parts was considered as the average from trees fertilized in the current year and those labelled in the previous year.

The amount of ${ }^{15} \mathrm{~N}$ from the fertilizer applied in the current year $\left(1966 \mathrm{mg}{ }^{15} \mathrm{~N}\right.$ tree $\left.{ }^{-1}\right)$, was significantly greater than the ${ }^{15} \mathrm{~N}$ from the fertilizer applied in the previous year (remobilized $\mathrm{N}$ ) (763 mg ${ }^{15} \mathrm{~N}$ tree ${ }^{-1}$ ) (Table 5 ). This was a consequence of greater biomass and increased fertilizer $\mathrm{N}$ use efficiency (FNUE) with plant age. Nevertheless, of the total $\mathrm{N}$ content of the 3 years old trees at the end of leaf fall, only about 10\% came from the fertilizer applied in that year, $4 \%$ was originated by previous year fertilization, and the remaining $86 \%$ came from other $\mathrm{N}$ sources (Table 5).

The relative importance of the remobilized $v s$. newly absorbed ${ }^{15} \mathrm{~N}$ in the new organs of 3 years old pear trees was different, as the remobilized ${ }^{15} \mathrm{~N}$ in the senescent leaves represented $71 \%$ of the ${ }^{15} \mathrm{~N}$ absorbed from the fertilizer in the current year, whereas in the new shoots and fine roots the importance of remobilized ${ }^{15} \mathrm{~N}$ was smaller, when compared to newly absorbed ${ }^{15} \mathrm{~N}$ (37\% and $28 \%$, respectively) (Table 5). This seems to indicate that leaves were more dependent on remobilized $\mathrm{N}$ than shoots and fine roots.
The $\mathrm{N}$ requirements were calculated for one to 3 years old 'Rocha'/BA29 pear trees, based on the characteristics of the trees coming from the nursery and on the trees fertigated for 3 years with $6 \mathrm{~g} \mathrm{~N}$ tree ${ }^{-1}$ year $^{-1}$. The difference between total $\mathrm{N}$ in year $(n)$ minus $\mathrm{N}$ stored in year $(n-1)$ resulted in estimated $\mathrm{N}$ needs of 2.5 , 4.8 and $14.4 \mathrm{~g} \mathrm{~N}$ per tree, in each of the first 3 years, respectively (Table 2). In accordance with the low FNUE of the trees and confirming what was stated above for each plant organ in 3 years old pear trees, the majority of the $\mathrm{N}$ came from other $\mathrm{N}$ sources than the mineral $\mathrm{N}$ fertilization $(84 \%, 83 \%$ and $86 \%$ in years 1,2 and 3 , respectively, calculated as the ratio $\left(1-{ }^{15} \mathrm{~N}\right.$ recovered from the fertilizer)/Nneeds (Table 2). The irrigation water in each year supplied $4 \mathrm{~g} \mathrm{~N}$ per tree, $6 \mathrm{~g} \mathrm{~N}$ per tree and $4 \mathrm{~g} \mathrm{~N}$ per tree in years 1 , 2 and 3 , respectively (data not shown).

\subsection{Nitrogen re-cycling from mineralization of fallen leaves}

A potential source of $\mathrm{N}$ in the soil comes from the decomposition of fallen leaves. One to three years old pear trees returned to the soil $0.6 \mathrm{~g} \mathrm{~N}$ tree $^{-1}$ year $^{-1}, 0.9 \mathrm{~g} \mathrm{~N}_{\text {tree }}^{-1}$ year $^{-1}$ and $1.4 \mathrm{~g} \mathrm{~N}$ tree ${ }^{-1}$ year $^{-1}$, respectively (Table 2 ) in the annual leaf fall. In the 4 years old pear trees fertilized with $10 \mathrm{~g}$ of senescent leaves $\left(0.094 \mathrm{~g}{ }^{15} \mathrm{~N}\right)$, the ${ }^{15} \mathrm{~N}$ recovered in the leaves of the mid third of 1 -year shoots sampled in August (5 months of leaf decomposition in the soil), reached $0.54 \pm 0.19 \%$ of the $\mathrm{N}$ derived from the addition of the senescent leaves, a low value, but nevertheless similar to those measured in May $(0.90 \pm 0.43 \% \mathrm{Ndff})$ and June $(1.20 \pm 0.75 \% \mathrm{Ndff})$ in the leaves of newly planted pear trees (2003) fertilized with $1.2 \mathrm{~g} N$ as labelled ammonium nitrate $\left(0.060 \mathrm{~g}{ }^{15} \mathrm{~N}\right.$ per month). If the ${ }^{15} \mathrm{~N}$ enrichment in the whole tree by leaf fall was the same as in August in the leaves of the mid third of 1-year-old shoots, and assuming that trees only accumulated over the fourth year the same amount of $\mathrm{N}$ as in the third year (13.48 $\mathrm{g} \mathrm{N}$ per tree), it would still represent a recovery of $50 \%$ of the $\mathrm{N}$ present in senescent leaves ( $73 \mathrm{mg} \mathrm{N}$ recovered in each tree compared with $151 \mathrm{mg} \mathrm{N}$ supplied by $10 \mathrm{~g}$ of senescent leaves). This means that over the season senescent leaves may contribute significantly to plant nutrition, under the present conditions.

\section{5. ${ }^{15} \mathrm{~N}$ balance in the soil-plant system}

Total $\mathrm{N}$ concentration in the soil decreased from the second to the third year of the experiment (Table 6). The percentage of ${ }^{15} \mathrm{~N}$ derived from the fertilizer and residual ${ }^{15} \mathrm{~N}\left(\mathrm{~g}\right.$ tree $\left.{ }^{-1}\right)$ in the soil were significantly greater in the upper soil layer $(0-20 \mathrm{~cm})$ in the two first years, but did not vary significantly with depth in the last year. The proportion of residual $\mathrm{N}$ in the soil coming from the fertilizer varied from $0.7 \%$ in the first year $(0-40 \mathrm{~cm})$ to $1.4 \%$ and $0.5 \%$ in the second and third years $(0-60 \mathrm{~cm})$, respectively (Table 6), considering the mean effect of soil depth.

Table 4

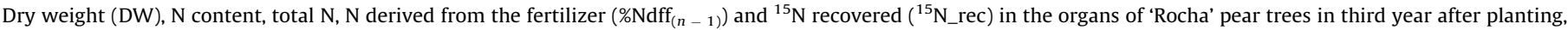
fertilized the year before with ${ }^{15} \mathrm{~N}$ enriched fertilizer

\begin{tabular}{|c|c|c|c|c|c|}
\hline Organ & DW $\left(\right.$ g tree $\left.^{-1}\right)$ & Total $\mathrm{N}\left(\mathrm{g} \mathrm{kg}^{-1} \mathrm{DW}\right)$ & $\mathrm{N}$ content $\left(\mathrm{g}_{\text {tree }}{ }^{-1}\right)$ & $\operatorname{Ndff}_{(n-1)}(\%)$ & ${ }^{15} \mathrm{~N} \_$rec $\left(\mathrm{mg}\right.$ tree $\left.{ }^{-1}\right)$ \\
\hline Sen. leaves & $110 \mathrm{c}$ & $12.0 \mathrm{~b}$ & $1.32 \mathrm{bc}$ & $5.6 \mathrm{~b}$ & $72 \mathrm{bc}$ \\
\hline Trunk & $544 \mathrm{~b}$ & 9.1 bc & $4.85 \mathrm{a}$ & $4.4 \mathrm{~b}$ & $212 \mathrm{a}$ \\
\hline Fine roots & $49 \mathrm{c}$ & $7.3 \mathrm{bc}$ & $0.35 \mathrm{c}$ & $4.4 \mathrm{~b}$ & $15 \mathrm{c}$ \\
\hline Coarse roots & 918 a & $6.2 \mathrm{c}$ & $5.71 \mathrm{a}$ & $4.2 \mathrm{~b}$ & $241 \mathrm{a}$ \\
\hline Shoots & $224 \mathrm{c}$ & $10.7 \mathrm{bc}$ & $2.35 \mathrm{~b}$ & $4.7 \mathrm{~b}$ & $106 \mathrm{~b}$ \\
\hline Shoots(n-1) & $103 c$ & $12.7 \mathrm{~b}$ & $1.22 \mathrm{bc}$ & $4.4 \mathrm{~b}$ & 52 bc \\
\hline Shoots(n-2) & $118 \mathrm{c}$ & $11.9 \mathrm{~b}$ & $1.35 \mathrm{bc}$ & $3.8 \mathrm{~b}$ & $54 \mathrm{bc}$ \\
\hline Flowers & $4 c$ & $29.2 \mathrm{a}$ & $0.10 \mathrm{c}$ & $10.2 \mathrm{a}$ & $11 \mathrm{c}$ \\
\hline Total & 2070 & - & 17.25 & - & 763 \\
\hline
\end{tabular}

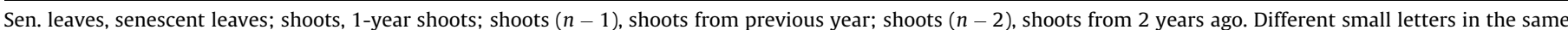
column and for each year differ significantly (Schéffé's test, $p<0.05$ ) between organs. 
Table 5

Source and age of nitrogen present in the different organs of young 'Rocha'/BA29 pear trees, at the end of the third year after planting

\begin{tabular}{|c|c|c|c|c|}
\hline \multirow[t]{2}{*}{ Organ } & \multicolumn{4}{|c|}{$\mathrm{N}$ content (g per tree) } \\
\hline & Total in the organ & Ndff of the year & Ndff of previous year & $\mathrm{N}$ from other sources \\
\hline Sen. leaves & 1.380 & 0.102 & 0.072 & 1.206 \\
\hline Trunk & 5.720 & 0.604 & 0.212 & 4.904 \\
\hline Fine roots & 0.390 & 0.054 & 0.015 & 0.321 \\
\hline Coarse roots & 5.460 & 0.446 & 0.241 & 4.773 \\
\hline Shoots & 2.475 & 0.288 & 0.106 & 2.081 \\
\hline Shoots(n-1) & 2.130 & 0.280 & 0.052 & 1.798 \\
\hline Shoots(n-2) & 1.745 & 0.192 & 0.054 & 1.499 \\
\hline Flowers & 0.120 & 0 & 0.011 & 0.109 \\
\hline Total & 19.420 & 1.966 & 0.763 & 16.691 \\
\hline
\end{tabular}

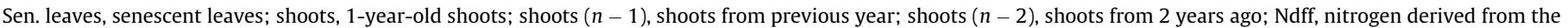
fertilizer $\left({ }^{15} \mathrm{~N}\right)$.

Since soil mineral $\mathrm{N}$ was low during the 3-year experiment (Table 6), it was only possible to determine the residual $\mathrm{N}$ nitrate- ${ }^{15} \mathrm{~N}$ content in 2003. In this year, the \%Ndff in the nitrate- $\mathrm{N}$ was $19.2 \%$, which represented $0.08 \mathrm{~g}^{15} \mathrm{~N}$ tree ${ }^{-1}$. As a result, the residual ${ }^{15} \mathrm{~N}$ (soil organic ${ }^{15} \mathrm{~N}+$ mineral ${ }^{15} \mathrm{~N}$ ) recovered in the maximum root volume of the pear trees was $0.29 \mathrm{~g}{ }^{15} \mathrm{~N}$ per tree, $2.37 \mathrm{~g}{ }^{15} \mathrm{~N}$ per tree and $0.83 \mathrm{~g}{ }^{15} \mathrm{~N}$ per tree in the first, second and third years, respectively, corresponding to $5 \%, 40 \%$ and $14 \%$ of the total ${ }^{15} \mathrm{~N}$ applied by fertilization (Fig. 2). The ${ }^{15} \mathrm{~N}$ accounted for in the soil-plant system over the 3-year experiment also reflected the increase in \%FNUE by the plants (6-33\%) from the first to the last year, as already mentioned. Estimated unaccounted for $\mathrm{N}$ varied from $89 \%$ to $46 \%$ and $53 \%$, in years 1,2 and 3, respectively (Fig. 2).

\section{Discussion}

Over the first 3 years after planting, the pear trees had increasing $\mathrm{N}$ requirements as a result of the growth of structural and storage organs. Estimated tree $\mathrm{N}$ requirements over the first 3 years after planting were about 3, 5 and $14 \mathrm{~g} \mathrm{~N}_{\text {tree }}^{-1}$ in each year, respectively (difference between total $\mathrm{N}$ in year $n$ minus $\mathrm{N}$ stored in year $(n-1)$ ) (Table 2 ), increasing exponentially with tree age and related mainly with the trunk biomass increase (which represented the main $\mathrm{N}$ storage organ). Thus, in young non-bearing pear trees, the FNUE would have to be at least $50 \%$ if plant needs were to be met by the fertilizer $\mathrm{N}$ applied ( $6 \mathrm{~g} \mathrm{~N}$ per tree), and even so, this $\mathrm{N}$ rate was clearly insufficient in the third year of planting. But this was not the case, since more than $80 \%$ of the $\mathrm{N}$ absorbed by the trees in the first 3 years after planting came from $\mathrm{N}$ sources other than the fertilizer applied (Tables 2 and 5). At the end of the third year, only $16 \%$ of the total $\mathrm{N}$ in the tree was derived from fertilizer applied in the last 2 years, contrasting with the 50\% obtained by Menino et al. (2007) in orange trees of the same age. It seems that in deciduous trees the importance of $\mathrm{N}$ reserves for sustaining growth and development is greater compared with citrus trees. Root pruning at planting probably delayed $\mathrm{N}$ uptake in this first year, making the newly planted trees even more dependent on the $\mathrm{N}$ reserves accumulated in the nursery for the initial vegetative growth (Fig. 1B). As a result, the quality of the plant material bought by farmers, which reflects the agricultural practices performed in the nursery, is crucial for the good establishment of an orchard, conditioning the future growth and development of newly planted trees.

The $\mathrm{N}$ pool size in the frame (trunk and shoots) was almost double that in the roots (Table 2 ). This was reflected in the increased shoot/root ratio of the non-pruned trees from the nursery (0.9) to the end of the third year (1.7). Although root pruning at planting aimed to obtain an equilibrium between shoot and root, in the absence of aerial pruning this ratio increased

Table 6

Residual $\mathrm{N}$ in the soil of pear orchard, over the 3-year experimental period

\begin{tabular}{|c|c|c|c|c|c|}
\hline Depth $(\mathrm{cm})$ & Organic $\mathrm{N}\left(\mathrm{g} \mathrm{kg}^{-1} \mathrm{DW}\right)$ & Mineral $\mathrm{N}\left(\mathrm{mg} \mathrm{kg}^{-1} \mathrm{DW}\right)$ & $\mathrm{Ndff}_{\mathrm{s}}(\%)$ & N_soil (g N tree ${ }^{-1}$ ) & ${ }^{15}$ N_res $\left(\mathrm{g} \mathrm{N}\right.$ tree $\left.^{-1}\right)$ \\
\hline \multicolumn{6}{|l|}{2003} \\
\hline $0-20$ & $0.57 \mathrm{aA}$ & $9.5 \mathrm{aA}$ & $0.97 \mathrm{a}$ & $14.7 \mathrm{a}$ & $0.14 \mathrm{a}$ \\
\hline $20-40$ & $0.62 \mathrm{aA}$ & $8.8 \mathrm{aA}$ & $0.42 \mathrm{~b}$ & $16.1 \mathrm{a}$ & $0.07 \mathrm{~b}$ \\
\hline Total & & & & 30.8 & 0.21 \\
\hline \multicolumn{6}{|l|}{2004} \\
\hline $0-20$ & $0.51 \mathrm{abA}$ & $2.6 \mathrm{aC}$ & $3.13 \mathrm{a}$ & $55.3 \mathrm{ab}$ & $1.69 \mathrm{a}$ \\
\hline $20-40$ & $0.63 \mathrm{aA}$ & $4.6 \mathrm{aB}$ & $0.68 \mathrm{~b}$ & $69.3 \mathrm{a}$ & $0.49 \mathrm{~b}$ \\
\hline $40-60$ & $0.47 \mathrm{bA}$ & $3.5 \mathrm{aC}$ & $0.37 \mathrm{~b}$ & $51.0 \mathrm{~b}$ & $0.19 \mathrm{~b}$ \\
\hline Total & & & & 175.6 & 2.37 \\
\hline \multicolumn{6}{|l|}{2005} \\
\hline $0-20$ & $0.36 \mathrm{aB}$ & $5.9 \mathrm{aB}$ & $0.84 \mathrm{a}$ & $48.6 \mathrm{a}$ & $0.44 \mathrm{a}$ \\
\hline $20-40$ & $0.49 \mathrm{aB}$ & $5.4 \mathrm{aB}$ & $0.41 \mathrm{a}$ & $65.0 \mathrm{a}$ & $0.27 \mathrm{a}$ \\
\hline $40-60$ & $0.37 \mathrm{aB}$ & $5.3 \mathrm{aB}$ & $0.24 \mathrm{a}$ & $49.7 \mathrm{a}$ & $0.12 \mathrm{a}$ \\
\hline Total & & & & 163.3 & 0.83 \\
\hline
\end{tabular}

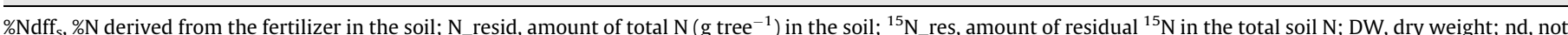

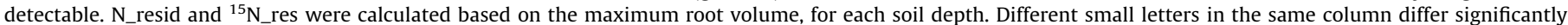

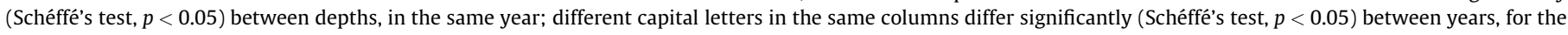
same soil depth. 


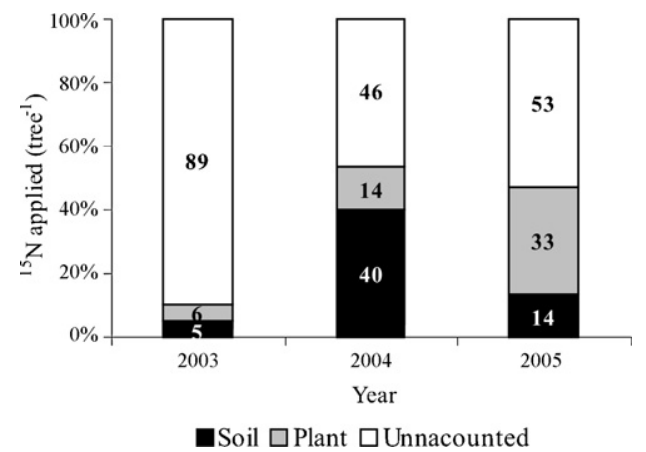

Fig. 2. Accounted and unaccounted ${ }^{15} \mathrm{~N}$ for the soil-plant system in the pear orchard, over the 3-year experimental period.

substantially during the first year (1.4), which led to a greater $\mathrm{N}$ accumulation in the aboveground organs.

The trunk contained $31-44 \%$ of the tree N, substantially more than the values obtained by Menino et al. (2007) in citrus of the same age (15\% in the first year and $5 \%$ the following 2 years). These results show the importance of the trunk as a storage organ in deciduous trees, whereas in evergreen trees the leaves constituted the most important reserve of $\mathrm{N}$ (Menino et al., 2007). The $\mathrm{N}$ stored in the frame of the young pear trees (trunk and shoots) was essential for supporting the new growth in the following spring, providing $32 \%$ and $54 \%$ of the ${ }^{15} \mathrm{~N}$ stored in the trunk and older shoots, respectively, to the growth of new organs (flowers, leaves and 1year-old shoots). Our results do not agree with those reported by Baherle et al. (1994) in peach, Marmann et al. (1997) in ash, Tagliavini et al. (1999) in nectarine, Frak et al. (2002) in walnut, Quartieri et al. (2002) in pear and Grassi et al. (2003) in cherry who estimated that in deciduous trees, roots were the main reservoir for $\mathrm{N}$ over winter. Nevertheless, they agree with the findings of Millard and Neilsen (1989) who stated that stems were the most important organs in remobilizing $\mathrm{N}$ to the new growth in 1-year-old M26 apple rootstocks. These differences may be due to different $\mathrm{N}$ supply (early, late or continuous $\mathrm{N}$ supply) which influences the pattern of plant uptake and partitioning of $\mathrm{N}$, affecting the spring remobilization of N (Quartieri et al., 1996; Neilsen et al., 1997; Tagliavini et al., 1999) but also because roots became more important for $N$ storage in older trees (Sanchez et al., 1991). Moreover, since the trees were sampled at leaf senescence, the global labelled $\mathrm{N}$ budget may underestimate the role of the roots in $\mathrm{N}$ remobilization to the new growth, given the importance of retranslocation of $\mathrm{N}$ in the phloem from shoots to roots (Millard and Neilsen, 1989). The absence of aboveground pruning could also have contributed to the greater storage importance showed by the trunk and older shoots.

At the end of the third year, the new organs (flowers, leaves, 1year-old shoots and fine roots) contained $204 \mathrm{mg}{ }^{15} \mathrm{~N}$ tree $^{-1}$, corresponding to $27 \%$ of the fertilizer ${ }^{15} \mathrm{~N}$ applied in the preceding year, a similar value to that obtained by Quartieri et al. (2002) in 2 years old 'Abbé Fétel' pear trees (23-24\%) in sand culture. In 3 years old Fagus sylvatica L., also in sand culture, the shoots and coarse roots contributed to the leaf biomass with $15 \%$ of the $\mathrm{N}$ absorbed in the previous year (Dyckmans and Flessa, 2001), whereas in 1-yearold walnut trees (Juglans nigra $\times$ regia) the remobilized $\mathrm{N}$ represented $54 \%$ of the $\mathrm{N}$ recovered in the new shoots after shoot growth cessation ( $50 \mathrm{~d}$ after bud break) (Frak et al., 2002). Since the young pear trees were sampled at leaf fall, the remobilized $\mathrm{N}$ was dependent on the unlabelled $\mathrm{N}$ fertilizer taken up by during that year, which, in turn, was affected by the $\mathrm{N}$ fluxes occurring inside the trees during the year leading to allocation and re-allocation of $\mathrm{N}$ between organs (aerial and subterranean) during the vegetative cycle (Grassi et al., 2003).
Comparing the distribution of plant ${ }^{15} \mathrm{~N}$ absorbed from the fertilizer in the current year and the amount of remobilized $\mathrm{N}$ coming from the fertilizer applied in the preceding year, the latter was more important in leaves (71\%), than in 1-year-old shoots (37\%) and fine roots (28\%) (Table 5). This was due to the fact that remobilization can occur until 45-70 d after bud break (Cheng et al., 2001, 2002; Grassi et al., 2002, 2003) while only a small $\mathrm{N}$ uptake from fertilizer occurs at this time (Quartieri et al., 1996; Tagliavini et al., 1997), especially due to low soil temperature in this period. Furthermore, rapid root growth does not start until after the rate of leaf growth decreases or ceases altogether (Millard and Neilsen, 1989).

The ${ }^{15} \mathrm{~N}$ enrichment in leaves collected from the medium third of 1-year-old shoots was used to establish the pattern of $\mathrm{N}$ uptake from the soil, assuming that roots did not discriminate between fertilizer and native soil N. Nitrogen uptake was very small during the first 2 months after bud break (April and May), and increased thereafter, stabilizing from June/July to the end of the growth cycle (Fig. 1). A similar trend was found in bearing 'Rocha' pear trees managed in similar conditions, although the \%Ndff in the leaves increased earlier (since May) and decreased sharply during senescence, revealing a greater $\mathrm{N}$ mobilization to storage organs (unpublished results). The increase of \%Ndff in the leaves was related with shoot growth, stabilizing when the growth ceased (August). In 3 years old peach trees (Prunus persicae (L.) cv. Maycrest) grafted on Nemaguard rootstock, grown in silicious sand and fertilized with a solution containing ${ }^{15} \mathrm{~N}$-enriched $\mathrm{KNO}_{3}$, maximum $\mathrm{N}$ absorption also took place during the periods of maximal vegetative growth (May-August) (Muñoz et al., 1993).

These results show that initial vegetative growth (in the first 23 months after bud break) was mainly dependent on $\mathrm{N}$ remobilization from storage organs and not directly from $\mathrm{N}$ taken up from the soil (Grassi et al., 2003; Guak et al., 2003). The pattern of fertilizer $\mathrm{N}$ uptake by these trees agreed with the findings of Cheng et al. (2001) and Neilsen et al. (2001a) that sustained that very small amounts of $\mathrm{N}$ were required until about 3 months after planting. Furthermore, the pear trees were root pruned before planting, compromising even more the $\mathrm{N}$ uptake during the first year as shown for root pruned 1-year-old 'Fuji' apples that took 76 days to attain similar levels of $\mathrm{N}$ uptake when compared with trees planted with intact root (Dong et al., 2003). In this case, carbon supply also limited N uptake (Lemaire and Millard, 1999) since the trees had few leaves to produce photo assimilates that could be transported to the roots. As a result of root pruning, a greater energetic investment in the recovery of the root system was required before it regained its functionality. From the discussion above, the statement that $\mathrm{N}$ should be supplied from bud break until the end of the cell division phase of the fruits ( 6 weeks after full bloom) (Gonçalves et al., 1997; Luz et al., 2005; Cavaco et al., 2006) does not seem adjusted to $\mathrm{N}$ requirements of non-bearing young trees.

The low \%Ndff recovery in the leaves until June partly explained the small \%FNUE observed in the young pear trees (6\%, 14\% and 33\% in the year 1, 2 and 3, respectively). Nevertheless, the value in the third year was considerably greater than the obtained in 5 years old 'Comice'/BA29 pear trees in the field (15-25\% FNUE) fertilized annually with $50 \mathrm{~kg} \mathrm{Nha}^{-1}$ as ammonium nitrate in a nonirrigated orchard (Sanchez et al., 1991; Righetti et al., 1994). Fertigation may have increased the FNUE of the pear trees in the present study since it provided a continuous N supply, enhancing its direct contact with the roots by the water flow. However, in a 3 years old 'Elstar' apple orchard, fertigated at a constant rate of $20 \mathrm{~g} \mathrm{~N}$ tree $^{-1}$ year $^{-1}$ as calcium nitrate, a smaller FNUE (22\%) was also observed (Neilsen et al., 2001b). In this case, the $\mathrm{N}$ supply in one single form $\left(\mathrm{NO}_{3}{ }^{-}\right)$was probably not as favourable as the 
fertilization with both $\mathrm{N}$ forms $\left(\mathrm{NO}_{3}{ }^{-}\right.$and $\left.\mathrm{NH}_{4}{ }^{+}\right)$, since leaching losses are less and $\mathrm{N}$ uptake by pear trees is greater when both $\mathrm{N}$ forms are present (Mengel and Kirkby, 2001). It must be stated, however, that the interpretation of the present experimental results were conditioned by the influence of the rootstock, the cultivar and the species itself on $\mathrm{N}$ uptake, $\mathrm{N}$ partitioning and $\mathrm{N}$ fertilization use efficiency (Neilsen and Neilsen, 1997). Furthermore, the fact that non-bearing trees were studied implies an extra precaution when comparing results obtained for bearing trees, since $\mathrm{N}$ partitioning in the tree is extremely dependent upon the sink/source balance between fruits and leaves (Righetti et al., 1994).

The senescent leaves returned to the soil $0.6 \mathrm{~g} \mathrm{~N}$ per tree, $0.9 \mathrm{~g} \mathrm{~N}$ per tree and $1.4 \mathrm{~g} \mathrm{~N}$ per tree through leaf fall in year 1,2 and 3, respectively (Table 2 ). Senescent leaves contained a smaller proportion of total $\mathrm{N}$ as trees aged (from 15\% to 7\% in the first and third years) (Table 2), but had an increasing ability to mobilize $\mathrm{N}$ to perennial storage organs before leaf fall ( $10 \%$ and $28 \%$ in the second and third years, respectively). Nitrogen withdrawal from senescent leaves can vary from $0 \%$ to $79 \%$ of their total N (Millard, 1996). This process depends mainly on the climatic conditions that preceded leaf abscission (Cheng et al., 2002), but also on crop load (Sanchez et al., 1991; Hörtensteiner and Feller, 2002) and tree N nutritional status (Millard and Thomson, 1989; Millard and Proe, 1991; Millard, 1996; Cheng et al., 2002). When extreme climatic or physiological conditions occur (e.g., very high or very low temperatures, nutritional deficiency or excess, water stress), leaf senescence is earlier and faster and $\mathrm{N}$ withdrawal decreases (Tagliavini et al., 2000; Hörtensteiner and Feller, 2002). In the first year after planting, early leaf senescence (November) probably affected $\mathrm{N}$ withdrawal from leaves, whereas in the second and third years leaf senescence occurred in December and an apparently greater withdrawal from the leaves before abscission took place. Although tree age has not been referred as a determinant factor in the variability of $\mathrm{N}$ withdrawal from senescent leaves, this could also have influenced our results.

The spring $\mathrm{N}$ remobilization was mostly dependent upon the direct uptake of $\mathrm{N}$ from the soil into the roots and stems for storage over the winter period, as already observed for other deciduous species (Millard and Proe, 1991).

Residual ${ }^{15} \mathrm{~N}$ in the soil was mostly accumulated in the upper soil layer (0-20 cm), especially in the organic form, due to the drop of plant material, root death, root exudates (Carranca et al., 1999) and microbial assimilation, representing 5\%, 40\% and $14 \%$ of the applied $\mathrm{N}$ in years 1, 2 and 3, respectively (Fig. 2). Unaccounted $\mathrm{N}$, which represents the potential $N$ losses, was $89 \%, 46 \%$ and $53 \%$ of the applied $\mathrm{N}$ in the first, second and third years, respectively (Fig. 2). These appreciable losses can be attributed to leaching or gaseous losses. Large $\mathrm{N}$ losses were also estimated by Menino et al. (2007) in young drip fertigated 'Lane Late'/'Carrizo' citrange citrus trees planted in a sandy soil under Mediterranean conditions (87\%, $69 \%$ and $53 \%$ in the first 3 years after planting, respectively). Climate, mainly the irregular rainfall distribution during the experimental period, may probably explain $\mathrm{N}$ losses by leaching, but also the gaseous losses, caused by the high air temperatures in the summer. In the present study, in the first year (2003), the amount of rainfall was $582 \mathrm{~mm}$, distributed in April (18\%) and October-November (70\%). As a result, part of the mineral $\mathrm{N}$ applied in April ( $20 \%$ of total $\mathrm{N}$ supplied) was possibly lost by leaching, due to the small root system and low activity. In October, the occurrence of $180 \mathrm{~mm}$ of rainfall probably also led to leaching losses. In the following years the rainfall distribution pattern was similar to the first year. Summarizing, in Mediterranean climates, the rainy spring and autumn pose serious risks in terms of fertilizer $\mathrm{N}$ losses by leaching. Since in those periods tree roots are not so active in taking up $\mathrm{N}$ from the soil, high $\mathrm{N}$ rates at these stages should be avoided.

Irrigation water was probably one of the alternative $\mathrm{N}$ source for the young pear trees, since it contained nitrate in appreciable amounts (about $5 \mathrm{~g} \mathrm{~N}-\mathrm{NO}_{3}{ }^{-}$tree $^{-1}$ year $^{-1}$ ). This $\mathrm{N}$ input must be considered when interpreting total $\mathrm{N}$ uptake by trees, as a more available, but also more prone to leaching $\mathrm{N}$ form. Soil organic matter mineralization, namely through the decomposition of the fallen leaves, could be another potential $\mathrm{N}$ source. Mineralization in this orchard occurred concurrently with tree $\mathrm{N}$ uptake, from July till November $\left(3.8-10.5 \mathrm{~kg} \mathrm{~N} \mathrm{ha}^{-1}\right)$, and $\mathrm{N}$ immobilization occurred immediately after the addition of senescent leaves to the soil (0.4-9.7 $\mathrm{kg} \mathrm{N} \mathrm{ha}^{-1}$ ) (Neto, unpublished results). From the data of the present study, the ${ }^{15} \mathrm{~N}$ abundance in the mid-third leaves of 1-year-old shoot of 4 years old pear trees was $0.372 \pm 0.002$ at. $\%{ }^{15} \mathrm{~N}, 5$ months (August) after the addition of senescent leaves to the soil. This low value was in the range of values measured in May and June in the same type of leaves of 1-year-old pear trees, fertilized with labelled mineral $\mathrm{N}$ fertilizer (Fig. 1B). Tagliavini et al. (2007) working with apple trees organically fertilized with ${ }^{15} \mathrm{~N}$ enriched senescent leaves under continental climatic conditions of Northern Italy, reported that, at the end of the first year the fruits, abscised leaves and pruning wood also had ${ }^{15} \mathrm{~N}$ abundances (average $0.377 \pm 0.004$ at.\% ${ }^{15} \mathrm{~N}$ ) slightly above the atmospheric ${ }^{15} \mathrm{~N}$ natural abundance, while after 2 years the trees had taken up $16 \%$ of the $\mathrm{N}$ initially present in the leaf litter, mostly in the tree framework (Tagliavini et al., 2007). It appears that in Mediterranean conditions, the contribution of $\mathrm{N}$ from leaf litter can be greater than in the North of Italy, since after 5 months the pear trees had taken up a similar amount of $\mathrm{N}$ compared to the apple trees after 12 months of organic fertilization and by leaf fall the trees had probably recovered half of the $\mathrm{N}$ applied via the senescent leaves. Further studies will be necessary to enlighten the role of senescent leaves in $\mathrm{N}$ re-cycling in fruit trees, since these are the only two studies available on this subject, and factors like leaf fall progression, wind leaf dispersal and cumulative senescent leaf deposition can affect the decomposition dynamics and $\mathrm{N}$ availability for trees in the field. At present, we think that most $\mathrm{N}$ taken up from soil derived from native organic $\mathrm{N}$, instead of senescent leaves, due to the small amount of $\mathrm{N}$ provided by these (1.4 $\mathrm{g}$ in the 3 years old trees).

\section{Conclusion}

In conclusion, young non-bearing 'Rocha' pear trees grafted on quince BA29 and planted in a Mediterranean region showed a continuous fertilizer $\mathrm{N}$ uptake over the growing season, but in the first 1-2 months after bud break $\mathrm{N}$ uptake was very low since the trees used mainly their stored $\mathrm{N}$ for the initial growth. As a result, the amount of $\mathrm{N}$ provided by fertigation should be reduced during the first 2 months after bud break, increasing towards June/July and maintaining a moderate $\mathrm{N}$ supply until the beginning of leaf fall. At this stage, split $\mathrm{N}$ should also be reduced in order to avoid greater $\mathrm{N}$ leaching losses. This $\mathrm{N}$ fertilizer distribution may help to increase the fertilizer $\mathrm{N}$ use efficiency by young non-bearing pear trees, which was particularly low in the first 2 years after planting, although increasing with age to a value considered favourable in the third year, compared with results from other tree species. Additionally, the $\mathrm{N}$ supply should also increase the $\mathrm{N}$ pool in trees, to be used for remobilization in the following year, avoiding potentially high $\mathrm{N}$ losses through leaching after leaf fall.

The main reserve organs in these young unprunned deciduous trees were the trunk and shoots, followed by coarse roots, which together accounted for most of the remobilized N. Since the estimated tree $\mathrm{N}$ requirements over the first years after planting were related with the increase in the trunk cross-sectional area, 
growth-based models could help to predict $\mathrm{N}$ needs, to be included in decision-support systems for fertilization recommendations.

\section{Acknowledgements}

This research was supported by the Portuguese government through the PIDDAC 111/02 project, by the FEDER/OE and "Fundação para a Ciência e a Tecnologia" (FCT) through the POCI/AGR/58325/04 project, and by a Ph.D. scholarship (BD/ $10188 / 2002)$ funded by FCT. Authors want to thank Inês Rocha for her technical assistance and Nuno Clemente for allowing the use of his orchard for the trials and for all the cooperation during the experimental period.

\section{References}

Baherle, P., Nuñez, I.P., Zapata, F., Glenn, D.M., 1994. Effect of 15N application time on the distribution of absorbed $15 \mathrm{~N}$ in peach trees. In: IAEA/FAO (Eds.), Proceedings of IFA/FAO Symposium: Nuclear Techniques in Soil-Plant Studies for Sustainable Agriculture and Environmental Preservation. pp. 709-710.

Carranca, C., de Varennes, A., Rolston, D.E., 1999. Variation in N-recovery of winter wheat under Mediterranean conditions studied with ${ }^{15} \mathrm{~N}$-labelled fertilizers. Eur. J. Agron. 11, 145-155.

Cavaco, M., Jordão, P., Sousa, R. de, 2006. Produção Integrada da Cultura de Pomóideas MADRP/DGPC, Oeiras.

Cheng, L., Dong, S., Guak, S., Fuchigami, L.H., 2001. Effects of nitrogen fertigation on reserve nitrogen and carbohydrate status and regrowth performance of pear nursery plants. Acta Hort. 564, 51-62.

Cheng, L., Dong, S., Fuchigami, L.H., 2002. Urea uptake and nitrogen mobilization by apple leaves in relation to tree nitrogen status in autumn. J. Hortic. Sci. Biotechnol. 77, 13-18.

Cheng, L., Ma, F., Ranwala, D., 2004. Nitrogen storage and its interaction with carbohydrates of young apple trees in response to nitrogen supply. Tree Physiol. 24, 91-98.

Dong, S., Cheng, L., Scagel, C., Fuchigami, L.H., 2003. Root damage affects nitrogen uptake and growth of young Fuji/M26 apple trees. J. Hortic. Sci. Biotechnol. 78, 410-415.

Dyckmans, J., Flessa, H., 2001. Influence of tree internal $\mathrm{N}$ status on uptake and translocation of $\mathrm{C}$ and $\mathrm{N}$ in beech: a dual ${ }^{13} \mathrm{C}$ and ${ }^{15} \mathrm{~N}$ labelling approach. Tree Physiol. 21, 395-401.

FAO-ISRIC-ISSS, 1998. World Reference Base for Soil Resources. World soil resources reports, 84: http://www.fao.org/docrep/W8594E/W8594E00.htm (accessed in July 29, 2006).

Frak, E., Millard, P., Le Roux, X., Guillaumie, S., Wendler, R., 2002. Coupling sap flow velocity and amino acid concentrations as an alternative method to ${ }^{15} \mathrm{~N}$ labeling for quantifying nitrogen remobilization by walnut trees. Plant Physiol. 130, 1043-1053.

Gonçalves, M., Cavaco, M., Sousa, A.J.T., Ferreira, J.T., Jorge, O., Avelar, M.L., Sousa, R. Costa, A.S.V., Calouro, F., Dias, J.C.S., Duarte, M.L.S., Jordão, P.M.B.V., 1997. Produção Integrada de Pomóideas-Planos de Fertilização e Práticas Culturais. DGDR, MADRP, Oeiras.

Grassi, G., Millard, P., Wendler, R., Minotta, G., Tagliavini, M., 2002. Measurement of xylem sap aminoacid concentrations in conjunction with whole tree transpiration estimates spring N remobilization by cherry (Prunus avium L.) trees. Plant Cell Environ. 25, 1689-1699.

Grassi, G., Millard, P., Gioacchini, P., Tagliavini, M., 2003. Recycling of nitrogen in the xylem of Prunus avium trees start when spring remobilization of interna reserves declines. Tree Physiol. 23, 1061-1068.

Guak, S., Neilsen, D., Millard, P., Wendler, R., Neilsen, G.H., 2003. Determining the role of $\mathrm{N}$ remobilization for growth of apple (Malus domestica Borkh.) trees by measuring xylem-sap N flux. J. Exp. Bot. 54, 2121-2131.

Hörtensteiner, S., Feller, U., 2002. Nitrogen metabolism and remobilization during senescence. J. Exp. Bot. 53, 927-938.

Jordão, P.M., 2002. Influência da fertilização azotada na produção da pereira cv. Rocha. Relação entre alguns aspectos da produção e a composição mineral das folhas e frutos. Ph.D. Thesis in Agronomic Engineering. Universidade Técnica de Lisboa, Instituto Superior de Agronomia, Lisboa.
Lemaire, G., Millard, P., 1999. An ecophysiological approach to modelling resource fluxes in competing plants. J. Exp. Bot. 50, 15-28.

Luz, R., Azevedo, J., Calouro, F., 2005. Fertilização. In: APAS, INIAP/ENFVN, LQARS, DGPC (Eds.), Manual Técnico de produção Integrada de pêra "Rocha", Cadaval, pp. $29-41$.

Marmann, P., Wendler, R., Millard, P., Heilmeier, H., 1997. Nitrogen storage and remobilization in ash (Fraxinus excelsior) under fields and laboratory conditions. Trees 11, 298-305.

Mengel, K., Kirkby, E.A., 2001. Principles of Plant Nutrition. Kluwer Academic Publishers, The Netherlands.

Menino, M.R., Carranca, C., de Varennes, A., 2007. Distribution and remobilization of nitrogen in young non-bearing orange trees grown under Mediterranean conditions. J. Plant Nutr. 30, 1083-1096.

Millard, P., 1996. Ecophysiology of the Internal Cycling of Nitrogen for Tree Growth. Z. Pflanzenernähr. Bodenk. 159, 1-10.

Millard, P., Neilsen, G.H., 1989. The influence of nitrogen supply on the uptake and remobilization of stored $\mathrm{N}$ for the seasonal growth of apple trees. Ann. Bot. 63, 301-309.

Millard, P., Thomson, C.M., 1989. The effect of autumn senescence of leaves on the internal cycling of nitrogen for the spring growth of apples. J. Exp. Bot. 40, 12851289.

Millard, P., Proe, M.F., 1991. Leaf demography and the seasonal internal cycling of nitrogen in sycamore (Acer pseudoplatanus L.) seedlings in relation to nitrogen supply. New Phytol. 117, 587-596.

Muñoz, N., Guerri, J., Legaz, F., Primo-Millo, E., 1993. Seasonal uptake of ${ }^{15} \mathrm{~N}$-nitrate and distribution of absorbed nitrogen in peach trees. Plant Soil 150, 263-269.

Neilsen, G.H., Neilsen, D., 1997. Orchard nutrition to maximize crop quality and minimize environmental degradation. Acta Hort. 448, 365-373.

Neilsen, D., Millard, P., Neilsen, G.H., Hogue, E.J., 1997. Sources of N for leaf growth in a high-density apple (Malus domestica) orchard irrigated with ammonium nitrate solution. Tree Physiol. 17, 733-739.

Neilsen, D., Millard, P., Herbert, L.C., Neilsen, G.H., Hogue, E.J., Parchomchuck, P., Zebarth, B.J., 2001a. Remobilization and uptake of $\mathrm{N}$ by newly planted apple (Malus domestica) trees in response to irrigation method and timing of $\mathrm{N}$ application. Tree Physiol. 21, 513-521.

Neilsen, D., Millard, P., Neilsen, G.H., Hogue, E.J., 2001b. Nitrogen uptake, efficiency of use, and partitioning for growth in young apple trees. J. Am. Soc. Hortic. Sci. $126,144-150$.

Ojea, F.G., Taboadela, M.M., 1957. El encalado de los suelos de zona humeda. Anales de Edafologia y Fisiologia Vegetal 11, 1017-1114.

Quartieri, M., Tagliavini, M., Scudellari, D., Marangoni, B., Millard, P., 1996. Assorbimento radicale di azoto e rimobilizzazione delle reserve azotate nel pero durante la ripresa vegetativa. Riv. Frutticoltura 10, 57-60.

Quartieri, M., Millard, P., Tagliavini, M., 2002. Storage and remobilization of nitrogen by pear (Pyrus communis L.) trees as affected by timing of $\mathrm{N}$ supply. Eur. J. Agron. 17, 105-110.

Raese, J.T., 1997. Cold tolerance, yield and fruit quality of 'd'Anjou' pears influenced by nitrogen fertilizer rates and time of application. J. Plant. Nutr. 20,1007-1102.

Righetti, T.L., Khemira, H., Sugar, D., Sanchez, E.E., 1994. Nitrogen requirements and nitrogen uptake efficiency for Comice pears. Acta Hort. 367, 304.

Sanchez, E.E., Righetti, T.L., Sugar, D., Lombard, P.B., 1991. Recycling of nitrogen in field-grown 'Comice' pears. J. Hortic. Sci. 66, 479-486.

Tagliavini, M., Quartieri, M., Millard, P., 1997. Remobilised nitrogen and root uptake of nitrate for spring leaf growth, flowers and developing fruits of pear (Pyrus communis L.) trees. Plant Soil 195, 137-142.

Tagliavini, M., Millard, P., Quartieri, M., Marangoni, B., 1999. Timing of nitrogen uptake affects winter storage and spring remobilization of nitrogen in nectarine (Prunus persica var. nectarina) trees. Plant Soil 211, 149-153.

Tagliavini, M., Inglese, P., Rombolá, A., 2000. Root uptake, storage and remobilization of autumn applied nitrogen to kiwifruit (Actinidia deliciosa) vines. Agronomie 20, 23-30.

Tagliavini, M., Tonon, G., Solimando, D., Gioacchini, P., Toselli, M., Boldreghini, P. Ciavatta, C., 2004. Nitrogen uptake by ryegrass (Lolium perenne) as affected by the decomposition of apple leaves and pruning wood in soil. In: Hatch, D.J. (Ed.), Proceedings of the 12th N Workshop: Controlling N flows and losses. Wageningen Academic Publishers, Wageningen, pp. 239-241.

Tagliavini, M., Tonon, G., Scandellari, F., Quiñones, A., Palmieri, S., Menarbin, G., Gioacchini, P., Masia, A., 2007. Nutrient recycling during the decomposition of apple leaves (Malus domestica) and mowed grasses in an orchard. Agric. Ecosys. Environ. 118, 191-200.

Westwood, M.N., 1993. Temperate-Zone Pomology: Physiology and Culture. Timber Press Inc., Oregon. 